\title{
Responsibilities of Industry Actors to Environmental Conservation in Coastal Areas
}

\section{La Ode Angga*, Rory Jeff Akyuwen, Adonia Ivone Laturette, Dyah R.A. Daties, Popi Tuhulele, Muchtar Anshary} Hamid Labetubun, Iqbal Taufik

Faculty of Law, Pattimura University, Ambon 97233, Indonesia

Corresponding Author Email: laodeangga@yahoo.com

https://doi.org/10.18280/ijsdp.160405

Received: 24 September 2020

Accepted: 30 June 2021

\begin{tabular}{l}
$\begin{array}{l}\text { Keywords: } \\
\text { responsibility, } \\
\text { environmental } \\
\text { areas }\end{array}$ \\
\hline
\end{tabular}

\begin{abstract}
The form of responsibility for industry players in maintaining the preservation of coastal areas in Wahai Seram Utara District, Central Maluku Regency based on Law Number 32 of 2009 concerning Environmental Protection and Management (UUPPLH), namely: Forms of state administrative legal accountability, forms of legal accountability civil and criminal legal liability forms.
\end{abstract}

\section{INTRODUCTION}

Coastal areas as a transitional area between terrestrial and marine ecosystems that are affected by changes in land and sea and small islands as islands with an area smaller than or equal to $2,000 \mathrm{~km}^{2}$ (two thousand square kilometers) and their unity of the ecosystem must be managed sustainably as an important part of development strategy to increase national competitiveness, in coastal and marine management efforts, the Ministry of Marine Affairs and Fisheries (DKP) of the Republic of Indonesia in 2001 identified three main problems, namely: (1) socio-economic problems, (2) institutional problems, (3) problems physical and (4) legal problems due to conflicts of authority and ownership of coastal and marine areas as well as uncertainty/ overlapping regulations in the legal sector [1].

In accordance with the essence of the Unitary State of the Republic of Indonesia as a constitutional state, the development of a Coastal Zone and Small Islands Management system as part of environmentally sustainable development must be provided with a clear, firm and comprehensive legal basis to ensure legal certainty for the management of Coastal Areas and Small Islands for this purpose the issuance of Law Number 27 of 2007 concerning Management of Coastal Areas and Small Islands (UUPWPPK) as a lex specialis in the management and protection of coastal areas and small islands in Indonesia. Apart from the UUPWPPK [2], there are also other laws and regulations that will provide legal protection for coastal areas and small islands which will be discussed in the next chapter.

The main issue in coastal areas is the rapid population growth that tends to live and do activities in coastal areas. As a strategic place, the coast is used for various things in the form of exploitation of fishery, forestry, oil, gas, mining and groundwater resources and others. Beach as a tourist area, conservation and biodiversity protection. The coast is also used as a place for development and improvement of infrastructure, including transportation, ports, airports, all of which are to meet the increasing population [3].

The environmental crisis is a very big challenge in this century. This challenge is found to apply especially in developing countries, because there are various development activities aimed at improving the welfare of mankind which often also have an impact on environmental changes. Development activities that are not accompanied by proper Environmental Protection and Management will result in calamity for mankind. Thus, the concept of supervision, management and implementation of environmental laws is the main key to achieving environmental sustainability [4].

Lothar Guilding, in his writing entitled Public Participation in Environmental Decision Making, suggests several bases for community participation to take environmental protection measures, namely in the following cases [5]:

1) Provide information to the government;

2) Increase people's willingness to accept decisions;

3) Assisting in legal protection;

4) Democratizing decision making.

Apart from these obligations, there is also the right of the community to obtain a good living environment as regulated in Article 28H paragraph (1) that "As a consequence of the right to a good and healthy environment, there is an obligation for everyone to maintain the environment in order to prevent and tackling environmental damage and pollution".

Because environmental management is an integrated effort to preserve environmental functions which includes policy, arrangement, utilization, development, maintenance, restoration, supervision and control of the environment, environmental management is carried out on the basis of state responsibility, sustainability and benefits [6].

This was then confirmed in the regulation in Law Number 32 of 2009 concerning Environmental Protection and Management (UUPPLH). The community's right to obtain a good living environment is formulated in Article 65 of the UUPPLH, namely [7]:

(1) Everyone has the right to a good and healthy environment as part of human rights. 
(2) Everyone has the right to environmental education, access to information, access to participation, and access to justice in fulfilling the right to a good and healthy environment.

(3) Everyone has the right to submit proposals and / or objections to the planned business and / or activity which is thought to have an impact on the environment.

(4) Everyone has the right to play a role in environmental protection and management in accordance with statutory regulations.

(5) Every person has the right to make a complaint due to the alleged pollution and / or damage to the environment.

(6) Further provisions regarding the procedure for complaints as referred to in paragraph (5) shall be regulated in a ministerial regulation.

From the rules of Article 65 UUPPLH, it can be seen clearly that the community has the right to a good social life and to a healthy environment. Companies and business actors must fulfill this right that is owned by the community in running the economic wheels of their company [8]. However, apart from rights, the UUPPLH also regulates the obligation to care for the environment for everyone as formulated in Article 67 that "Every person is obliged to maintain the preservation of environmental functions and control environmental pollution and / or damage."

Furthermore, for companies or business actors that carry out business activities, the obligation to preserve the environment is regulated in Article 68 that "Every person conducting a business and / or activity is obliged to [9]:

a) Provide information related to environmental protection and management in a correct, accurate, open and timely manner;

b) Maintaining the sustainability of environmental functions;

c) Comply with the provisions regarding environmental quality standards and/ or environmental damage standard criteria.

The area that owns the sea area is given the authority to manage resources in the sea area. Regions get profit sharing for the management of natural resources below the bottom and / or on the seabed in accordance with statutory regulations so that the regions are also entitled to carry out development up to exploration and exploitation of living and non-living natural resources along the coast to their ocean territory. However, the granting of this authority will also have a negative consequence for the national coastal and marine areas to suffer physical damage on a severe scale. The damage includes coastal abrasion and sedimentation, reduced fish production due to overfishing (overfishing) in several marine locations, damage to coral reef ecosystems and mangrove forests, and damage to sea water quality due to coastal and marine pollution. These include administrative, legal issues such as regional autonomy, increased Regional Original Income (PAD), regional and sectoral conflicts which are problems that must be resolved together through integrated coastal area management.

Another thing is also because there is no environmental awareness for industry players, as according to Muhammad Akib that "environmental awareness is a concern or concern for the world community towards the environment as a result of various environmental problems [10]. As according to Jimly Asshiddiqie, that: 'in on the one hand, everyone has the right to a good and healthy environment, but on the other hand, everyone is also obliged to protect and respect the rights of others to obtain and enjoy a good and healthy environment [11].

Including in this case, one of the industry players who have responsibility for the preservation of coastal areas is a shrimp pond cultivation industry company, namely Wahana Lestari Investama Limited Liability Company in North Seram District, Central Maluku Regency, Maluku Province. Shrimp pond cultivation industry company is one type of company that manages and utilizes natural resources, which is a fishery industry, which means the business of raising and breeding shrimp, namely shrimp which is used as raw material for production [12].

Wahana Lestari Investama Limited Liability Company first operated in North Seram District, Maluku Tengah District, Maluku Province in 1994 until now, Wahana Lestari Investama Limited Liability Company has several times changed the name of the company and changed the owner of Limited company Jayanti Group was replaced with Limited company Mina Seram Lestari was later replaced by Limited company Nipon Suizan Indonesia (NISUI) after that was replaced with Limited company MSL, and finally replaced by Wahana Lestari Investama Limited Liability Company until now, but before changing its name to Wahana Lestari Investama Limited Liability Company, the company experienced problems where the company stopped operating until 30 October 2004, Limited company NISUI took over the shrimp pond cultivation company from Limited company Jayanti Group. Since then until now where the company has been chaired by Wahana Lestari Investama Limited Liability Company has 16 years with a 30 year contract period on the land on which there is a shrimp pond. However, until now the local community has not felt the touch of the responsibility of the industrial company Wahana Lestari Investama Limited Liability Company towards the preservation of coastal areas, in this case is a legal obligation mandated to industrial companies.

A survey conducted by Sayange.com, there are several problems that occur in the community that industrial companies ignore their social and environmental responsibilities. So that the action carried out by the North Seram Youth and Student Care Alliance (IPPEMASUT, GMNI, PMKRI), demanded that Wahana Lestari Investama Limited Liability Company was revoked because it had polluted the environment and marine biota ecosystem in the area around the company. Besides that, Wahana Lestari Investama Limited Liability Company also does not make a good contribution to the welfare of the community, even though there is an MoU between the community and the company [13]. In addition, a survey conducted by Siwalimanews.com stated that there is a disposal of liquid waste and disposal of factory waste in the form of shrimp heads carried out by Wahana Lestari Investama Limited Liability Company, which reached thousands of tons, which is very disturbing for the community [14].

From the description above, in order to protect the marine environment which includes coastal areas, waters and small islands, especially in Wahai, Seram Utara District, Central Maluku Regency from various forms of pollution, the authors see the need for research that examines laws and regulations that provide legal protection against various potential pollution to coastal areas in Wahai District, Central Maluku. From the above background, the formulation of the problem to 
be examined in this paper is: What is the form of legal responsibility for industry players in maintaining the preservation of coastal areas in Wahai, North Seram District, Central Maluku Regency?

\section{LITERATURE REVIEW}

\subsection{Theoretical framework}

The theory used as a knife of analysis in answering the problem formulation in this study, namely: a. Welfare Law State Theory, b. The theory of legal liability.

\subsubsection{The welfare law state theory}

According to Logemann, the state is a social organization that aims with its power to regulate and organize a society [15]. The state as a legal entity is a personification of the national legal order that forms a community, therefore from a legal point of view, the State issue appears as a national legal order issue. Plato argued that good governance of the state is based on good (law) regulation. In the 1945 Constitution of the Republic of Indonesia Article 1 paragraph (3) it is stated that "the State of Indonesia is a State of Law", this means that "the life mechanism of individuals, society and the State is regulated by law (both written and unwritten) so that both members of society and the government are obliged to obey the law".

The rule of law theory is considered a universal theory, which in its implementation has a variety of characters, this is due to the nation's philosophy, state ideology and others. In the Continental European legal system (civil law), the rule of law is known as Rechtsstaat. The rule of law according to Continental Europe must meet four conditions as Freidrich Julius Stahl said in his book Ridwan HR, namely:

a.Protection of Human Rights;

b.Separation or distribution of powers to guarantee those rights;

c. Government based on the Prevailing Laws;

d.Administrative justice in disputes [16].

The elements of a rule of law (Rechtsstaat) as conveyed by Sri Soemantri include:

a. That the government in carrying out its duties and obligations must be based on the law;

b.There is a guarantee of human rights (citizens);

c. There is a division of power within the state;

d.The existence of supervision and judicial bodies (rechterlijke controle) [17].

In the formulation of the 1945 Constitution of the Republic of Indonesia, Article 1 paragraph (3) states that "Indonesia is a State of Law". The Unitary State of Indonesia is a country which in carrying out governance is based on legal principles to limit government power, this means that the State's power is limited by law (Rechtsstaat), not based on mere power (machtsstaat) which is clearly defined in the Body of the Constitution 1945. Thus, in the administration of government implemented based on the system of government by $\mathrm{KC}$ Wheare stated, "the first of all it is used to describe the whole system of government of a country, the collection of rule is partly relieved, in the sense that the courts of law ill recognized as law but which are not less effective in regulating the government than the rules of law strictly so called".

Based on the elements of the rule of law described above, the writer prefers to relate to this research, namely the principle of legality (legal certainty). A legal certainty will run effectively if it is supported by good law enforcement [18]. Because the benefits of law are felt when the dominant legal subject gets the benefits of happiness. Fairness, certainty and benefits provide a significant function for maintaining environmental management in an environmentally sound manner. However, it cannot be carried out simultaneously because the duties and functions are different.

\subsubsection{Accountability theory}

The theory of legal responsibility is closely related to the theory of rights and obligations. a theory of rights is a theory that emphasizes the notion of rights which is coupled with the notion of obligations. The general opinion is that rights to someone are always correlated with obligations to others [19].

A theory related to the theory of legal liability is the theory of legal responsibility. That a person is legally responsible for certain actions or that he bears legal responsibility, meaning that he is responsible for a sanction if his actions are contrary to applicable regulations. According to Hans Kelsen in his theory of legal responsibility states that a person is legally responsible for a certain act or that he is responsible for the law, the subject means that he is responsible for a sanction in the case of acts that are contrary [20].

Traditional theory distinguishes two types of responsibility (responsibility), namely: responsibility based on elements of error, and absolute responsibility.

In certain situations, a person can be held responsible for civil wrongdoing by another person, even though the act against the law was not his fault. This kind of thing is known as responsibility for the mistakes done by others. The theory of responsibility based on illegal acts committed by other people can be divided into 3 (three) categories as follows:

a. The responsibility of the boss

b.Replacement responsibility which is not from the supervisor of the dependents

c. Responsibility for the replacement of goods under his responsibility.

The Civil Code explains that several parties must accept responsibility for illegal acts committed by other parties as follows [21]:

a.Parents or guardians who are responsible for acts committed by children under their dependents or guardians.

b.Employers are responsible for the actions taken by their workers.

c. The teacher is responsible for his pupil.

d.The head craftsman is responsible for the actions taken by the workers who are under him.

e. The owner of the animal is responsible for the actions taken by his pet.

$\mathrm{f}$. The building owner is responsible for the collapse of the building due to negligence in maintenance or due to defects in its construction or layout.

In general, the principle of responsibility in law can be distinguished as follows [22]:

Principle of Responsibility Based on the Elements of Faults (Liability based on fault). This principle is a fairly general principle that applies in civil law, especially Articles 1365, 1366, and 1367 of the Civil Code. In general, this principle of responsibility is acceptable because it is fair for the person who made a mistake to compensate for the loss for the victim. In other words, it would be unfair for an innocent person to compensate for the harm suffered by others [23]. 
The case that needs to be explained in this principle is the definition of the subject of the wrongdoer which in the legal doctrine is known as the principle of vicarious liability and corporate liability.

Vicarious liability implies that the employer is responsible for other party's losses incurred by the person or employee under his / her supervision. Corporate liability has the same meaning as vicarious liability. According to this doctrine, the institution that houses a group of workers has responsibility for the workforce it employs. This kind of problem is not simple, because in practice it is not certain that every carrier is willing to admit his mistake. If this is the case, then the passenger, sender or recipient of the goods or the third party may not act unilaterally and must be able to prove that the loss occurred because of the carrier error. The proof is carried out in court to be decided by the judge.

The Principle of Presumption to Always be Responsible (presumption of liability). This principle states that the defendant is always held responsible until he can prove his innocence. So, the burden of proof lies with the defendant. If the defendant cannot prove the transporter's error, then compensation will not be given [24].

In connection with this principle of responsibility, four variations are recognized in the doctrine of the law of transportation:

a. The carrier can free himself from responsibility if he can prove that the loss is caused by things outside his control.

b. The carrier can free himself from responsibility if he can prove that he is taking the necessary action to avoid the occurrence of a loss

c. The carrier can release himself from his responsibility if he can prove that the loss was not due to his fault

$\mathrm{d}$.The carrier is not responsible if the loss is caused by passenger error or poor quality of goods.

e.Presumable Principle Not Always Responsible (Presumption Nonliability Principle)

This principle is the opposite of the principle of presumption to always be responsible. This principle is known only in a very limited scope of consumer transactions. This principle is more applied to cases such as cases where in the event of a traffic accident, the plaintiff is the plaintiff who has an active role in proving.

Based on the explanation in Law Number 22 Year 2009, the application of this principle can be seen from Article 194 paragraph (1) which states that public transportation companies are not responsible for losses suffered by third parties, unless the third party can prove that such losses. caused by an error by the Public Transportation Company so that he can claim compensation for the losses he suffered.

Principle of Absolute Responsibility (strict liability). The principle of absolute responsibility is often identified with the principle of absolute responsibility. Some say absolute responsibility is a principle that determines error not as a determining factor. On the other hand, absolute responsibility is responsibility without error and there are no exceptions.

The principle of absolute responsibility is one of the types of Civil Liability [25]. Civil liability is a civil law instrument in the context of law enforcement to obtain compensation.

Criminal liability theory. Criminal liability is imposing a penalty on the maker for an act that violates the prohibition or creates a prohibited situation. Criminal responsibility therefore relates to the process of transferring the existing punishment to the criminal act to the maker. To account for someone in criminal law is to pass on a sentence that objectively exists in a subjective criminal act against the maker. Criminal liability is determined based on the fault of the maker and not only on the fulfillment of all elements of the criminal act.

Thus, error is placed as a determining factor for criminal responsibility and is not only seen as a mental element in a criminal act [26]. A person declared to have an error is a matter of criminal liability [27].

To be able to impose a sentence on a perpetrator for committing a criminal act, the legal rules regarding criminal liability serve as a determinant of the conditions that must exist on a person so that they are valid if sentenced. Criminal liability which concerns the problem of the maker of a criminal act, rules regarding criminal liability are regulations on how to treat those who violate obligations. So the actions that are prohibited by the community are accountable to the perpetrator, meaning that the objective punishment of the sentence is then passed on to the accused. Criminal liability without the fault of the party who violates cannot be accounted for [28]. So a person who cannot possibly be accounted for and be convicted if he does not commit a criminal act. But even though he committed a criminal act, he could not always be convicted.

Van Hamel, said that criminal liability is a normal condition and psychological maturity that brings three kinds of abilities to: (a) Understand the meaning and consequences of one's own actions; (b) Recognizing that his actions are not justified or prohibited by society, and (c) Determining the ability to act.

Furthermore, the basis for the existence of a crime is the principle of legality while the basis for the conviction of the maker is the principle of guilt. This implies that the perpetrator or perpetrator of a criminal act can only be convicted if he has a mistake in committing the crime. When a person is said to have a mistake is a matter of criminal liability.

According to Simons, as the basis for criminal responsibility is a mistake in the soul of the perpetrator in relation (the mistake) with the behavior that can be convicted and based on that psychology the perpetrator can be criticized for his behavior. For the existence of an error to the perpetrator, several things related to the perpetrator must be reached and determined, namely [29]:

a. Responsible ability;

b.The psychological relationship between the perpetrator and the resulting consequences (including behavior that is not contrary to the law in everyday life;

c.Dolus and culpa, error is a subjective element of crime. This is a consequence of his opinion linking (unifying) straafbaarfeit with errors.

The element of criminal action in criminal law is also called the element of offense (element of offense). The offense element is part of the offense. In prosecuting an offense, all the elements of the offense accused must be proven against the offender. Therefore, if one of the elements or elements of the offense is not fulfilled, then the offender cannot be blamed for committing the accused offense, so that the offender must be released from all lawsuits (onslaag van rechts alle vervologing). The offense element is generally divided into 2 (two) parts, namely: (1) the objective element, or what is commonly known as the actus reus, and (2) the subjective element, or what is commonly called the mens rea.

Objective offense elements are elements that have to do 
with conditions, namely in which circumstances the actions of the perpetrator must be carried out. The objective elements of a criminal act include: (a) the unlawful nature, (b) the quality of the perpetrator, for example the condition of being a Civil Servant (PNS) as regulated in Article 415 of the Criminal Code, and (c) causality, the relationship between an act cause with reality as result. Objective offense elements are elements of offense related to the actions (act, daad) of the offender, namely:

a. Form of action (active, passive), or visible result

An offense can be manifested by active behavior or passive behavior, in accordance with the description of the offense that requires it. For example, in an ordinary theft offense (Article 362 of the Criminal Code), the form of the act is to partially or completely take other people's property. Another example is an offense for not fulfilling summons in court as a witness, expert, interpreter (Article 224 KUHP) [30]. So the form of the act referred to is active or passive, including the type of commission offense, or the type of omission offense, or delictum commissionis per ommissionem commissa, or the offense for not obeying the prohibition is continued by not doing it [31].

b. The act must be against the law;

The action required to fulfill the objective offense element is that in doing the act there must be an element against the law (wedderectelijkheids, unlawful act, onrechtma-tigedaad). An act against the law is an act which is prohibited from being obeyed, or ordered not to be done as stated in the criminal rules. Criminal Law distinguishes the nature against the law into 2 (two) main meanings, namely:

c. Against the law in a formal sense.

Zainal Abidin [32] explained that it is said to be formal because the criminal law prohibits or orders the act is accompanied by the threat of sanctions to anyone who violates or ignores it. The meaning of an act against formal law is constitutive elements, which are in every formulation of offenses in a written criminal code, even though in reality it is not written with a duty to be against the law. Thus, if it is not stated, it means that the element against the law is accepted as a brand element (accepted tacitly, implicitly). Against formal law, he is more concerned with legal certainty (rechtszekerheids) which comes from the principle of legality (benginsel legaliteit).

\subsection{Conceptual framework}

\subsubsection{Hudup environmental management}

The term environment, in English is called environment, in Dutch it is called millieu or in French it is called environment, while according to S.J. McNaughton and Larry L. Wolf define this by all external factors of a biological and physical nature which directly affect the life, growth, development and reproduction of organisms. Furthermore, Otto Soemarwoto stated that "living environment is defined as the space occupied by a living being along with living and inanimate objects in it [33]. Meanwhile, Munadjat Danusaputro, a leading environmental law expert and Professor of Environmental Law, Padjajaran University, defines the environment as all objects and conditions, including humans and their actions, which are contained in the space where humans live and affect the life and welfare of humans and other living bodies.

The definition of environment is also formulated in Article 1 number 1 UUPPLH, that: "The environment is a spatial unit with all objects, forces, conditions, and living things, including humans and their behavior, which affect nature itself, the continuity of life and human welfare. and other living things".

\subsubsection{Coastal areas}

Often the use of the terms beach and coast is not defined clearly and with certainty. When viewed juridically, the two must be given a clear meaning. Reinterpretation of the two terms is intended to avoid doubt or uncertainty, both in the formulation of a regulation and in its implementation. The following is the definition of beaches and coasts according to Diraputra's opinion in Nanin Triayanawati that [34]:

"The beach is the area where the highest tide meets the land. Meanwhile, the coastline is a line connecting the meeting points between the highest tide and the land. The coastline will be formed following the land / coastal land configuration itself".

"Coastal is the meeting area between land influence and ocean influence. Inland covers certain areas where the influence of the oceans is still felt (sea breezes, temperature, plants, seabirds, etc.) While towards the ocean, coastal areas include areas of the sea where the effects of land activities are still felt or are still visible (for example, sightings. pollutants, sedimentation and water color.)".

As a transitional area influenced by land and sea, according to Bengen in Mukhtasor, dividing the coastal area into 2 (two) parts which include:

1) Inland coastal areas;

As an area where the land borders the sea, which is still influenced by marine processes such as tides, sea breezes, and salt intrusion.

2) The coastal sea area;

It is an area that is influenced by natural processes on land, such as sedimentation and the flow of fresh water into the sea, as well as a marine area that is influenced by human activities on land.

According to Ongkosongo, the definition of beach is as follows [35]:

"The area around the tide is usually called the coast, and the land boundary with the sea is more commonly called the coast. Onshore is the term direction from land to sea. Inshore is the coastal area until the area where the waves start to break. Meanwhile, the term offshore is an area from a rather steep sea slope on the coast to around the continental shelf. For activities at sea level or near sea level, the term "on sea" is used. A sloping and sandy beach is called a gisik ("beach").

Meanwhile, the distinction between coastal, physical, and coastal definitions was put forward by Suwardi as follows:

1) A shore is an area bounded by a low tide water level to the land where the sea water reaches its maximum.

2) Gisik (beach) is a beach covered by sand and gravel.

3) Coast is an area bounded by the backshore coast to the land to the extent that the influence of sea water is still there, such as sea water intrusion or sea breeze.

Apart from the expert's opinion, several laws have also provided definitions of coast and coast, although in very general terms. In particular, according to the UUPWPPPK as a lex specialis it provides the following definitions of coast and coast:

Article 1 paragraph (2);"Coastal areas are transitional areas between terrestrial and marine ecosystems which are affected 
by changes in land and sea."

\subsubsection{Coastal zone pollution}

The term pollution has often been heard in public forums or mass media, but the general public, even educated people can have different definitions or meanings of pollution in general, as well as coastal and marine pollution in particular.

The following are some definitions of pollution and destruction from the coast and small islands:

PWPPPK Law Article 1 paragraph (28):

"The entry or inclusion of living things, substances, energy, and / or other components into the coastal environment as a result of people's activities so that the quality of the coast drops to a certain level which causes the coastal environment to not function according to its designation."

The definition of pollution and destruction based on this law is very important because this law will be used as a frame work in providing protection for coastal areas and small islands including the waters in between. However, the definition of pollution here only regulates pollution that occurs in coastal areas such as the following example of Article 1 paragraph 28 UUPWPPPK that "... so that the quality of the coast decreases ... which causes the coastal environment to not function ..." this article does not cover pollution in coastal waters. Even though coastal waters are included in the scope of management and utilization of coastal areas.

\section{RESEARCH METHOD}

This research is normative juridical research, that is research conducted on legal principles, in the sense of concrete legal values (norms) [36] and legal systems [37]. The approach used in research [38] is the statute approach. and conceptual approach [39].

\section{RESULTS AND DISCUSSION}

\subsection{Responsibilities of industry players}

Responsibility in the General Indonesian Dictionary, means the condition of being obliged to bear everything (if there is something, it can be sued, blamed, sued, etc.) [40]. Responsibility by definition is human awareness of behavior or actions, whether intentional or unintentional. Responsibility also means acting as a manifestation of awareness of obligations.

Legal responsibility originates or arises from the use of facilities in the application of each person's ability to exercise their rights or / and carry out their obligations. Every exercise of obligations and every use of rights, whether done insufficiently or adequately, basically must be accompanied by accountability, as well as the exercise of power. Every claim for accountability in law must have a basis, namely things that cause a person to be (obliged) responsible. According to civil law, the basis of responsibility is the mistakes and risks that exist in every legal event [41].

Legal responsibility is a further consequence of the implementation of roles, both roles are rights and obligations or power. Legal responsibility is defined as the obligation to do something or behave in a certain way not to deviate from the existing regulations [42]. In essence, only each individual can be responsible. Only those who bear the consequences of their actions. Therefore, the term personal responsibility or responsibility itself is actually "redundant". A society which does not recognize that every individual has his own value and which he is entitled to is unable to respect the dignity of that individual and is unable to recognize the nature of freedom.

In general, the principles of responsibility in law can be distinguished as follows:

1) Responsibility based on the element of error. The principle of responsibility based on the elements of error (fault liability or liability based on fault) is a fairly general principle in criminal and civil law. As in the principle of criminal law, namely "There is no crime without error" and in civil law, it is an act against the law in Article 1365 of the Civil Code.

2) The Principle of Presumption to Always be Responsible. This principle states that the defendant is always held responsible (the presumption of liability principle, until he can prove his innocence. This is especially true when the defendant actually committed an act that harmed others.

3) Presumption Not Always Responsible This principle is the opposite of the second principle. The principle of the presumption of not always being responsible is known only in a very limited scope of consumer transactions.

4) Principle of Absolute Responsibility The principle of absolute responsibility (strict liability or absolute liability). According to E. Suherman, Strict Liability is equated with Absolute liability, in this principle there is no possibility to free oneself from responsibility, except if the loss arises due to the fault of the party who is injured himself.

5) Liability with Restrictions

Business actors like this principle of responsibility with limitations (Imitation of liability principle) to be included as an exonation callusula in the standard agreement they make. As for the principles of responsibility in environmental law:

1) Social responsibility

Social responsibility as in the 1945 Constitution, in article $28 \mathrm{H}$ paragraph (1), which reads as follows: "Everyone has the right to live in physical and mental prosperity, to live, and to get a good and healthy environment and the right to obtain health services. " The same rights are also regulated in Article 9 of Law No. 39 of 1999 concerning Human Rights, as follows: Paragraph (2) "Everyone has the right to live in peace, security, peace, happiness, physical and spiritual prosperity."

Paragraph (3) "Everyone has the right to a good and healthy environment" [43].

2) Absolute Liability (strict liability)

\subsection{A form of legal responsibility for industry players in maintaining the preservation of coastal areas in Wahai, Seram Utara District, Central Maluku Regency}

A company or industry that runs its business in a community environment will more or less cause various impacts. Whether it's negative or positive impacts, and every company must have responsibility for every activity it carries out. Every company has a social responsibility towards society and the environment. To realize this form of responsibility, each company has a different way.

In the event of environmental pollution by the company, the 
company must be able to be responsible for preserving the environment due to pollution, therefore broadly the authors classify the principle of corporate responsibility for environmental pollution, namely regarding the principle of corporate social responsibility, the principle of legal responsibility, and politics. administrative (political) responsibilities. Overall, these responsibilities will be explained more clearly through responsibilities.

Everyone whose actions, business, and / or activities use to produce and / or manage B3 waste, and / or which pose a serious threat to the environment, are absolutely responsible for the losses incurred without the need to prove the element of error (principle strict liability), and in the principle of social responsibility is also known as the principle of accountability by companies due to environmental pollution.

Seeing all the provisions stipulated in UUPPLH, the authors qualify regarding general corporate responsibility, namely civil liability, criminal liability and administrative responsibility. These accountability accounts are described as follows:

\subsubsection{Civil liability}

According to Article 1 number (5) PERMEN No. 13 of 2011 concerning Compensation for Pollution and / or Environmental Damage, Compensation is a cost that must be borne by the person in charge of activities and / or business due to environmental pollution and / or damage.

According to Article 87 paragraph (1) of Law no. 32 of 2009 concerning Environmental Protection and Management ("UUPPLH"):

"Every person in charge of a business and / or activity that has committed an illegal act in the form of pollution and / or environmental destruction that causes harm to other people or the environment is obliged to pay compensation and / or take certain actions."

In civil law, it regulates compensation for actions against the law. What is meant by an act of violating the law is an act committed by one or more parties which has harmed the other party. Actions that violate the law by one party or better if it is done intentionally or unintentionally will of course harm other parties whose rights have been violated (Article $1365 \mathrm{BW}$ ).

What is meant by an act violating the law according to Article 1365 of the Civil Code, is "every act violating the law, which brings harm to another person, obliges those who because of their mistake to issue the loss, compensate the loss". An act against the law is an act that violates law, morality, public interest, and propriety. So, every person or business entity committing acts against the law (environmental pollution) must be responsible for the losses suffered by the community or the government and other parties. These responsibilities are in the form of civil, criminal and administrative liability. For this reason, regarding the provision of compensation or compensation, namely relating to civil responsibility on the basis of an act against the law.

Furthermore, in the Regulation of the Minister of the Environment Number 13 of 12 concerning Compensation for Environmental Pollution and / or Damage, it explains things regarding compensation as follows:

Article 3:

"The person in charge of a business and / or activity committing an unlawful act in the form of pollution and / or environmental damage causing harm to other people or society and / or the environment or the state is obliged to:

a) perform certain actions; and / or b) pay compensation".

Article 4:

"The obligation to take certain actions as referred to in Article 3 letter a includes:

a) prevention of environmental pollution and / or destruction;

b) overcoming pollution and / or damage to the environment; and / or

c) restoration of environmental functions".

Article 5:

(1) Environmental losses as referred to in Article 3 letter b include:

a) losses due to the failure to carry out the obligation to treat wastewater, emissions, and / or manage hazardous and toxic waste;

b) losses to compensate for the costs of overcoming pollution and / or environmental damage and restoring the environment;

c) losses to compensate for the costs of verifying complaints, inventorying environmental disputes, and monitoring costs of paying compensation and implementing certain actions;

d) losses due to loss of biodiversity and reduced environmental function; and / or

e) public losses due to environmental pollution and / or damage.

(2) Losses due to pollution and / or environmental damage as referred to in paragraph (1) are grouped into losses which:

a) is permanent; and

b) is not permanent.

(3) Losses as referred to in paragraph (1) letter a to letter $\mathrm{d}$ are permanent losses.

(4) The losses as referred to in paragraph (1) letter e are non-permanent losses

Article 6:

(1) The calculation of compensation must be carried out by an expert who meets the following criteria:

a) has a certificate of competence; and / or

b) has conducted scientific research and / or has experience in the fields of:

1) environmental pollution and / or damage; and / or

2) environmental economic evaluation.

Article 7:

"The calculation of compensation for environmental pollution and / or damage as referred to in Article 5 shall be carried out in accordance with the procedure for calculating the compensation as stated in the Appendix which is an integral part of this Ministerial Regulation".

\subsubsection{Criminal liability}

"There is no crime without fault" and no criminal responsibility without a criminal act "the term is a theory of liability in criminal law. A person / business entity (corporation) who commits a criminal act is obliged to be accountable for his actions. UUPPLH has regulated criminal liability for companies that do damage or pollute the environment, as explained in the articles drawn below. Article 116:

1) If an environmental crime is committed by, for, or on behalf of a business entity, the criminal charges and criminal sanctions are imposed on:

a) business entity; and / or 
b) the person who gave the order to commit the criminal act or the person who acted as the leader of the activity in the criminal act.

2) If the environmental crime as referred to in paragraph (1) is committed by a person who is based on a work relationship or based on other relationships acting within the scope of work of a business entity, criminal sanctions shall be imposed on the person who gave the order or leader in the criminal act without regard to the criminal act can be done individually or together.

Article 117:

"If a criminal charge is filed against the giver of the order or the commander of the criminal act as meant in Article 116 paragraph (1) letter $b$, the punishment imposed is in the form of imprisonment and a fine heavier by one third".

Article 118:

"With regard to the criminal act as referred to in Article 116 paragraph (1) letter a, the criminal sanction is imposed on the business entity represented by the management authorized to represent inside and outside the court in accordance with statutory regulations as a functional actor".

Article 119:

"In addition to the crimes referred to in this Law, business entities may be subject to additional penalties or disciplinary measures in the form of:

a) confiscation of profits derived from a criminal act;

b) closing all or part of the place of business and / or activity;

c) corrections due to criminal acts;

d) the obligation to do what was neglected without the right; and / or

e) placing the company under interdiction for a maximum period of 3 (three) years".

\subsubsection{Administrative responsibilities}

The running of a company requires legal certainty of the right to establish and carry out its business activities. For this reason, in legalizing the standing and running of business activities in a company, it requires the participation of the government to issue a decision regarding the legality of the standing and running of a business activity. The form of legality is established and the operation of a company is about the issuance or granting of permits by the government.

Each company is obliged to carry out its duties and responsibilities in accordance with the applicable regulations as described in various applicable regulations, especially in the scope of the UUPPLH. UUPPLH regulates environmental friendly provisions, therefore a business activity or company in carrying out its production process must pay attention to the situation and conditions of the surrounding environment. This means that if there is a violation by the company resulting in environmental damage or pollution, then the company can be held accountable for its actions. For this reason, it is related to the duties and responsibilities of the government that has issued a business license to a company, then the relevant government is constitutionally obliged to revoke the license. The UUPPLH regulates the administrative responsibility of a company, as explained by the articles below:

Article 76:

(1) The Minister, governors or regents / mayors shall apply administrative sanctions to the person in charge of a business and / or activity if a violation of the environmental permit is found under supervision.
(2) Administrative sanctions consist of:

a) written warning;

b) government coercion;

c) freezing of environmental permits; or

d) revocation of environmental permits.

Article 77:

"The Minister can apply administrative sanctions against those in charge of businesses and / or activities if the Government considers that the regional government has deliberately not applied administrative sanctions for serious violations in the field of environmental protection and management".

Article 78:

(1) The administrative sanctions as meant in Article 76 do not exempt the person in charge of a business and / or activity from the responsibility for recovery and punishment.

Article 79:

"The imposition of administrative sanctions in the form of suspension or revocation of environmental permits as referred to in Article 76 paragraph (2) letters c and d is carried out if the person in charge of a business and / or activity does not implement government coercion".

\section{CONCLUSIONS}

The responsibility of industry actors for the preservation of coastal areas in Wahai, Seram Utara district, Central Maluku regency, is in the form of responsibility for preserving the environment, so that the environment remains beautiful according to its designation. So that the environment can be inherited from present generations to future generations.

\section{REFERENCES}

[1] Mukhtasor, (2007). Pencemaran Pesisir dan Laut, Pradnya Paramita, Jakarta. https://opac.perpusnas.go.id/DetailOpac.aspx?id=39386.

[2] Undang-undang Nomor 7 Tahun 2007 UUPWPPK. https://adoc.pub/bab-ii-peraturan-perundang-undanganyang-memberikan-perlindu.html.

[3] Pramudya, A. (2008). Kajian Pengelolaan Daratan Pesisir Berbasis Zonasi di Provinsi Jambi, Semarang: Tesis Pasca Sarjana Magister Teknik Sipil Universitas Diponegoro.

http://openjournal.unpam.ac.id/index.php/rjih/article/vie w/2981.

[4] Djamin, D. (2007). Pengawasan dan Pelaksanaan Undang-Undang Lingkungan Hidup: Suatu Analisis Sosial, Jakarta: Yayasan Obor Indonesia. https://onesearch.id/Record/IOS1.INLIS000000000017 338.

[5] Siahaan, N.H.T. (2004). Hukum Lingkungan dan Ekologi Pembangunan, Jakarta: Erlangga. http://opac.ut.ac.id/detail-opac?id=28531.

[6] Syahrin, A. (2009). Beberapa Isu Hukum Lingkungan Kepidanaan, Medan: Sofmedia. https://www.worldcat.org/title/beberapa-isu-hukumlingkungan-kepidanaan/oclc/434018833.

[7] Undang-Undang Nomor 32 Tahun 2009 tentang Perlindungan dan Pengelolaan Lingkungan Hidup (UUPPLH). https://referensi.elsam.or.id/2015/04/uu- 
nomor-32-tahun-2009-tentang-perlindungan-danpengelolaan-lingkungan-hidup-

2/\#: :text=Perlindungan\%20dan\%20Pengelolaan\%20Li ngkungan $\% 20$ Hidup $\% 20$ (PPLH) $\% 20$ menurut $\% 20 U U \%$ 20no\%2032,meliputi\%20perencanaan $\% 2 \mathrm{C} \% 20$ pemanfa atan $\% 2 \mathrm{C} \% 20$ pengendalian $\% 2 \mathrm{C}$.

[8] Beby, S. (2010). Corporate Social Responsibility (CSR) menurut Undang-Undang Nomor 40 Tahun 2007 tentang Perseroan Terbatas, Tesis Master Kenotariatan, Universitas Sumatera Utara, Medan. http://repositori.usu.ac.id/handle/123456789/33325.

[9] Manik, K.E.S. (2003). Pengelolaan Lingkungan Hidup, Jakarta Djambatan https://www.worldcat.org/title/pengelolaan-lingkunganhidup/oclc/645923946.

[10] Akib, M. (2014). Hukum Lingkungan: Perspektif Global dan Nasional, Rajawali Pers, Jakarta. http://www.rajagrafindo.co.id/produk/hukumlingkungan-perspektif-global-dan-lingkunganmuhammad-akib/.

[11] Asshiddiqie, J. (2010). Green constitution: nuansa hijau undang-undang dasar negara republik Indonesia Tahun 1945, Rajawali Pers, Jakarta. https://library.ui.ac.id/detail?id=20228260.

[12] Angga, L.O., Datie, D.R.A., Tuhulele, P., Fataruba, S., Taufiq, I. (2021). Responsibility of manufacturers in waste management of plastic packaged drink products based on law number 18 of 2008 regarding waste management (Case study in Ambon city, Maluku province). International Journal of Sustainable Development and Planning, 16(2): 327-334. https://doi.org/10.18280/ijsdp.160212

[13] www.siwalimanews.com/post/akademisihentikanoperas i pt.wli. Diakses Tanggal 15 Maret 2020. https://siwalimanews.com/.

[14] Khairunnisa, D. (2009). Kedudukan, Peran dan Tanggung Jawab Hukum Direksi Dalam Pengurusan BUMN, Tesis, Program Pascasarjana Program Ilmu Hukum. Universitas Sumatra Utara, Medan. http://repository.usu.ac.id/handle/123456789/5394.

[15] Yu lies Tiena Masriani. (2014). Pengantar Hukum Indonesia, Jak arta: Sinar Grafika. http://inlislite.uinsuska.ac.id/opac/detail-opac?id=18219.

[16] Ridwan, H.R. (2003). Hukum Administrasi Negara, Yogyakarta: UII Press. http://perpus.litbang.esdm.go.id/user/book/5.

[17] Soemantri, S. (1992). Bunga Rampai Hukum Tata Negara Indonesia, Bandung: Alumni. https://opac.perpusnas.go.id/DetailOpac. aspx?id=43505 5.

[18] Wheare, K.C. (1975). Modern Constitutions, London: Oxford University Press.

[19] Santoso, M.A. (2005). Good Governance \& Hukum Lingkungan, Jakarta:

ICEL. https://opac.perpusnas.go.id/DetailOpac.aspx?id=97094

[20] Kalsen, H. (2006). Teori Umum tentang Hukum dan Negara, PT. Raja Grafindo Persada Bandung. Jakarta. https://onesearch.id/Record/IOS3774.JAKPU00000000 0112763.

[21] Kitab Undang-Undang Hukum Perdata (KUHPerdata). https://id.wikisource.org/wiki/Kitab_UndangUndang_Hukum_Perdata.

[22] Celina Tri Siwi Kristiyanti. (2008). Hukum Perlindungan konsumen, PT. Sinar Grafika, Jakarta. http://ailis.lib.unair.ac.id/opac/detail-opac?id=48543.

[23] Siombo, M.R. (2012). Hukum Lingkungan dan Pelaksanaan Pembangunan Berkelanjutan di Indonesia, (Jakarta: Gramedia Pustaka Utama. https://www.gpu.id/book-detail/86240/hukumlingkungan-dan-pelaksanaan-pembangunanberkelanjutan-di-indonesia.

[24] Suherman, E. (2000). Aneka Masalah Hukum Kedirgantaraan (Himpunan Makalah 1961-1995), Mandar Maju, Bandung. https://www.worldcat.org/title/aneka-masalah-hukumkedirgantaraan-himpunan-makalah-19611995/oclc/44775518.

[25] Salim, H.S. (2000). Pengantar Hukum Perdata Tertulis (BW), PT. Sinar Grafika, Jakarta: 2008. https://library.ui.ac.id/detail?id=20371418.

[26] Huda, C. (2004). Dari Tiada Pidana Tanpa Kesalahan Menuju Kepada Tiada Pertanggungjawaban Pidana Tanpa Kesalahan, Kencana Prenada Media, Jakarta. http://lib.ui.ac.id/detail?id=20294456.

[27] Priyatno, A. (2004). Kebijakan Legislasi Tentang Sistem Pertanggungjawaban Pidana Koorporasi di Indonesia, CV. Utomo, Bandung. http://repository.unpar.ac.id/handle/123456789/1996.

[28] Adji, O.S. (1991). Etika Profesional dan Hukum Pertanggungjawaban Pidana Dokter, Penerbit: Erlangga, dan Kenpaniteraan. http://pustaka.pu.go.id/biblio/teorihans-kelsententanghukum/E7J46.

[29] Sarwono. (2012). Hukum Acara Perdata Teori Dan Praktek, Jakarta: Sinar Grafika. http://opac.ut.ac.id/detail-opac?id=31577.

[30] Soekanto, S., Mamudji, S. (1985). Penelitian Hukum Normatif Suatu Tinjuan Singkat. Jakarta: CV. Rajawali Press. https://opac.perpusnas.go.id/DetailOpac.aspx?id=11749 06.

[31] Zainal Abidin Farid, H.A. (2007). Hukum Pidana I, Sinar Grafiika, Jakarta. https://opac.perpusnas.go.id/DetailOpac.aspx ?id=25988 0.

[32] Sumarwoto, O. (1991). Ekologi, Lingkungan Hidup dan Pembangunan, Djambatan, Jakarta. https://onesearch.id/Author/Home?author=Otto+Soemar woto.

[33] Nanin Triayanawati Sugito dan Dede Sugandi, Urgensi Penentuan Dan Penegakan Hukum Kawasan Sempadan Pantai,

http://file.upi.edu/Direktori/B\%20\%20FPIPS/JUR.\%20 PEND.\%20GEOGRAFI/195805261986031\%20\%20DE DE\%20SUGANDI/sempadan\%20pantaiDed\%20S.pdf. diakses tanggal 21 Januari 2020.

[34] Kusumaatmadja, M. (1993). Segi-Segi Pengelolaan Daerah Pesisir dan Pantai Menurut Wawasan Nusantara, (Hasil Kerja Sama Badan Penelitian dan Pengembangan Masalah Luar Negeri Departemen Luar Negeri R.I. dan Pusat Studi Wawasan Nusantara Hukum dan Pembangunan. https://inspire.unsrat.ac.id daring.

[35] Marzuki, P.M. (2008). Penelitian Hukum., Jakarta: Prenada Media Group. https://onesearch.id/Author/Home?author=Peter+Mahm ud+Marzuki.

[36] Angga, L.O., Latupono, B., Labetubun, M.A.H., Fataruba, S. (2020). Application of hawear customary law in the prevention of pollution and environmental 
damage on the sea coast in southeast Maluku regency. International Journal of Sustainable Development and Planning, 15(5): 767-774. https://doi.org/10.18280/ijsdp.150519

[37] Asshiddiqie, J., Safa'at, M.A. (2006). Teori Hans Kelsen tentang hukum. Mahkamah Konstitusi RI, SekretariatJenderal. https://pustaka.pu.go.id/biblio/teorihans-kelsen-tentang-hukum/E7J46.

[38] Marzuki, P.M. (2009). Penelitian hukum. Kencana Prenada Media Group, Jakarta, 211-213. http://lib.ui.ac.id/detail?id=20373484.

[39] Poerwadarminta, W.J.S. (1985). Kamus Umum Bahasa Indonesia, Jakarta: Balai Pustaka. https://opac.perpusnas.go.id/DetailOpac.aspx ?id=53000 9.

[40] Purbacaraka. (1978). Perihal Kaedah Hukum, Bandung:
Citra Aditya. https://library.ui.ac.id/detail?id=20453072.

[41] Undang-Undang Nomor 39 Tahun 1999 Tentang Hak Asasi Manusia (HAM). https://id.wikisource.org/wiki/Undang-

Undang_Republik_Indonesia_Nomor_39_Tahun_1999.

[42] Peraturan Menteri Lingkungan Hidup Nomor 13 tahun 2012 Tentang Ganti Rugi Terhadap Pencemaran dan/atau Kerusakan Lingkungan. https://mahesainstitute.web.id.

[43] Peraturan Menteri Dalam Negeri Nomor 13 Tahun 2011 Tentang Pedoman Pelaksanaan Tugas Kehumasan Di Lingkungan Kementerian Dalam Negeri Dan Pemerintah Daerah. https://jdih.baliprov.go.id/produkhukum/peraturan-perundang-

undangan/permendagri/3423\#: :text=Peraturan $\% 20 \mathrm{Me}$ nteri\%20Dalam\%20Negeri\%20Nomor,Dalam\%20Nege ri\%20Dan\%20Pemerintah\%20Daerah. 